Vol. 8, No. 1 (2011) | ISSN 2160-5807(online) | DOI 10.5195/ppr.2011.14 | http://ppr.pitt.edu

\title{
The Next American Century
}

\section{A Traditional Hard Power Problem or a New World Order?}

\author{
Thomas Visco and Alex Zimmerman \\ Senior Editor and Staff Writer
}

\begin{abstract}
There is a general consensus that the new world order gathered steam in response to World War II. Major institutions like the United Nations, NATO, and the Universal Declaration of Human Rights all fortified the common belief that economic, social, and political interdependence is unavoidable. This international framework in which both domestic and foreign policies have far-reaching and unclear implications is not well understood. Important debates concerning economic and military intervention in developing countries, the scope and enforceability of human rights, and the role of international governing bodies are far from settled. This raises an important question for the United States: What ought to be the values that define American foreign policy given these highly contentious circumstances? More specifically, should the United States rely primarily on its military strength as leverage? Can the U.S. maintain its superpower status? What might this look like in the future and is this desirable? These are the questions that will guide a discussion between Thomas Visco and Alex Zimmerman.
\end{abstract}

Keywords: globalization, military, American foreign policy

\section{(c)) EY-NC-ND}

This work is licensed under a Creative Commons Attribution-Noncommercial-No Derivative Works 3.0 United States License.

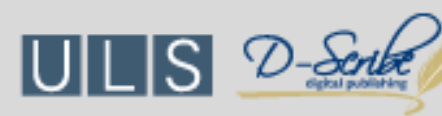

This journal is published by the University Library System of the University of Pittsburgh as part of its D-Scribe Digital Publishing Program, and is cosponsored by the University of Pittsburgh Press. 


\section{The Next American Century}

\author{
A Traditional Hard Power Problem or a New \\ World Order?
}

\section{Thomas Visco and Alex Zimmerman \\ Senior Editor and Staff Writer}

Alex:

More than ten years ago, Thomas Friedman made the argument that globalization is an inevitable international reality and that the United States has a vested interest in fostering "sustainable globalization". Instead of a world defined by bipolarity and the power of nation states to maintain order, the symbol of globalization is the Internet - "a symbol that we are all connected and nobody is quite in charge." ${ }^{1}$ Friedman's thesis that America's overwhelming national interest in free markets and representative government across the world also comes with a responsibility to ensure that massive injustice does not follow, has to a large extent, been ignored. Moreover, it has been ignored at a significant cost. While it is true that military power is still relevant - and there are varieties of hard security threats to be sure - the force of the American military will not solve the problems that will increasingly characterize life in the age of globalization.

\section{Thomas:}

The problems that will "increasingly characterize" globalization are unknown at this point. Although we may know the ingredients for these challenges - increased nuclear proliferation in a host of nations (most notably Iran), energy conflict in Eastern Europe, disputes in South Asia, and the rise of China to global prominence-we cannot be sure what form they may take. The United States needs a concrete, positive foundation in order to maintain international power. The most natural home for this foundation is military strength. America needs to be ready to face unknown threats of the future. These challenges may take many forms. The only way to ensure US interests in this new age is a solid, intelligent national defense strategy.

Alex:

I agree that American foreign policy needs a concrete foundation, but it is not obvious and it is also problematic to assume that it should be housed in the Pentagon. Yes, the United States has an incredibly powerful military with a global reach, but this is hardly justification for using it as the primary mode of achieving America's objectives. America's top foreign policy goal should be to develop a strategy that is dynamic and not confined to one particular conception of power in the international system. These traditional power structures are quickly eroding. What should America's foreign policy objectives be in your view? It is interesting that you mention China as a security threat in the same paragraph that you say the problems of globalization are "unknown." Sixty years ago, China was considered an economic basket case. Today, it is one of the strongest economies in the world because of liberalizing trade standards and a huge domestic labor force. I am entirely unconcerned that China will launch an attack on the United States. I am concerned that the economic institutions created by our trade relationship with China exploit millions, and are the single greatest threat to political instability in the country. It is not just that the problems of globalization are new; it is that we need new tools to find effective solutions.

Thomas:

I have no interest in America holding dominion over the world. A desire to continue international prominence is not the same as starting an imperial project. Military power is not just warfare. Military power is providing unique capabilities and bargaining tools to policymakers. What policy future politicians want to make, I have no idea. If you want to claim that the new age of globalization is coming and we better get ready, how do we prepare for the unknown without a national defense? In a world where Iran is only several years from the atomic bomb, Russia's ambitions necessitate expansion, and China's military is adapting to the modern age, what do we offer our allies in terms of support? How do we restrain 
Israel from a regionally catastrophic preemptive strike on Iran? How do we maintain NATO? How do we stay prominent in the South Pacific? We do it now through our influence. This influence is directly connected to our military capabilities.

Alex:

There is no question that national defense is important, but historically, massive counterinsurgency efforts have been justified under this heading. The lesson of Vietnam, Iraq, and Afghanistan is that counterinsurgency efforts that rely on the Powellian notion of "shock and awe" do little else than breed antiAmericanism: they create more enemies than they destroy. There is no question that the Iraqis disliked Saddam Hussein, but they also hated indiscriminate American bombing.

Let me offer a more affirmative view of how I think American policy should reflect an increasingly globalized world. Instead of doubling down on the traditional conception of power you offer that has done little in the past decade to successfully create a positive international image of America - this is a serious foreign policy and security concern-we should be leaders in coming up with frameworks that allocate responsibility when human rights are violated. We should be on the cutting edge of green technological innovations that minimize our dependence on authoritarian regimes. In China, American and Chinese companies are fostering a class of workers who are unable to live minimally decent lives according to the Universal Declaration of Human Rights. We should be offering multilateral and even military assistance to those who are trying to break free of the tyranny of dictatorship. These problems are both causally and morally connected to the conduct of individual American consumers as well as to the U.S. government. And shifting American policy to meet these new challenges is justified given your conception of the importance of domestic security. If America fails to engage $21^{\text {st }}$ century problems, it will take a back seat to whoever does.

Thomas:

Surely, the people of Afghanistan and Iraq were trying to break free of tyranny in 2001 and 2003 respectively. I feel your perceived " $21^{\text {st }}$ century problem" of human rights violations is a moment of historical forgetfulness. Have human rights been an underwhelming problem up until 2001? The World Bank, founded in 1944 in Washington D.C., has distributed billions of dollars in development funds, as has the International Monetary Fund and the United States' government. The 1999 NATO Air Campaign against Yugoslavia, which the United States led, was instrumental in stopping a massive humanitarian crisis in Eastern Europe. What would the world look like if we enacted your $21^{\text {st }}$ century solutions? I find it hard to believe that America's enemies will pack their things and go home. You are not describing new problems. A changing economy, a shrinking world, revolutionary thoughts and ideas spreading across the globe, a new sense of what it is to be a human, and what human dignity is; humanity has been here before. Indeed, we are entering uncertain times. Yet, America's strategy of hard power, coupled with evolving foreign policy strategies, has been very successful in the past half-century. Better yet, it has been the most successful strategy out of all nations. We should not be quick to change it. If we want the American Century to continue we need to continue to evolve our strategy, learn from our mistakes, and maintain our cohesive, successful foreign policy based on military strength.

That is not to say I disagree with radical changes entirely. In this decade, which is surely to be remembered as a decade of austerity, the United States needs to revolutionize how it maintains domestic and international security. For example, we must learn from 


\section{PPR PIT POLITCLLL EEVEN}

Vol. 8, No. 1 (2011) ｜ＩSSN 2160-5807 (online) ｜ DOI 10.5195/ppr.2011.14 | http://ppr.pitt.edu

Israel and China in the ways of cyber warfare. We must maintain and expand our fleet of unmanned fighting vehicles to keep our reach abroad, while keeping our men and women on our shores. Both of these reduce our man-power commitment, and decrease our reliance on traditional hard power capital (tanks, artillery, small arms). This can be done within the confines of budget reductions. Many studies have introduced comprehensive plans to continue American influence and global engagement while cutting \$100-200 billion from the Pentagon Budget. ${ }^{2}$ Most of these include reduction in foreign deployment, which is less necessary as our global air power becomes more absolute, and reduction in research and development projects.

Alex:

The foreign policy perspective I am offering accommodates reduced defense spending because I do not believe we need to be prepared to fight other industrial nations. The kind of spending that will positively affect our position in the world-foreign aid, domestic investment in education, infrastructure, and green energy technology - are small in relation to the roughly $\$ 500$ billion each year that is spent on maintaining our hard power presence in the world. Interestingly, much of what I am recommending as a new direction for American foreign policy is required before we can claim the next century as an "American Century". It is not just that America is loosing its status in the world because of our foreign policy mistakes; we must seriously consider the ways in which we are falling behind as educators and innovators. This is connected to our ability to have the right international orientation. Given my foreign policy perspective, we can both strengthen our influence in the world and reprioritize our commitment to defense spending.

\section{Thomas:}

Over the past half-century, the military has been the backbone of American foreign policy. The United States Navy brought aid to Haiti after cataclysmic earthquakes; the United States Air Force dropped ordinance that saved countless lives in Yugoslavia; and in Pakistan, the combined operations of US Joint Special Operations Command clinically struck Osama Bin Laden's compound in Pakistan. Today, carrier battle groups travel the seas, ensuring allies that the United States is a partner they can take shelter in during these times of uncertainty. America should have many priorities; education, infrastructure, and international justice are all important. Yet, in the coming century of globalization, the foundation of America's power will be, as always, a strong national defense capable of projecting a complex strategy of global engagement.

Authors

THOMAS VISCO is a junior studying politics and philosophy.

ALEX ZIMMERMAN is a senior studying politics and philosophy. If you would like to hear more witty banter on serious issues, you can download their podcast $\boldsymbol{E x}$ Post Facto at www.wptsradio.org.

Notes

${ }^{1}$ Thomas Friedman, Longitudes and Attitudes: Exploring the World After September 11. (New York: Farrar, Straus \& Giroux, 2002), 4.

${ }^{2}$ Lieutenant General David Barno, Dr. Nora Bensahel and Travis Sharp, "Hard Choices, Responsible Defense in an Age of Austerity," Responsible Defense at the Center for a New American Security, October 3, 2011, Internet (accessed December 4, 2011). 